\title{
Preliminary Observations on the Early Stages of Scatella stagnalis Fal. (Ephydridae, Diptera).
}

\author{
By
}

Purnendu Sen, M.Sc, Ph.D.(Lond.), D.I.C.

Entomology Department, Imperial College of Science and Technology, London.

With 4 Figures in the Text.

\section{CONTENTS.}

1. Introduction . . . . . . . . . . . . 847

2. Material . . . . . . . . . . . . . . . . 847

3. Egg . . . . . . . . . . . . . . . . . . . . 848

4. Larva . . . . . . . . . . . . . . . . . . . 848

(i) First Instar . . . . . . . . . . . . . . . . . . . 848

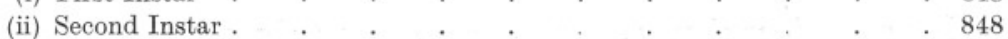

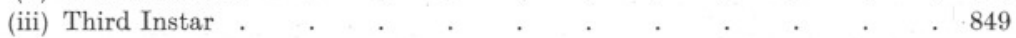

5. Pupa

References

\section{Introduction.}

THE insects, Scatella stagnalis, ${ }^{*}$ for the present study were collected from the Marine Biological Laboratory at Plymouth at the kind suggestion of Dr. Allen, F.R.S., the Director of the Laboratory, during my short stay there in the summer of 1929. So far as I can see, no work on the early stages of the genus Scatella is available. This led me to put on record the present account of the different pre-imaginal stages of the insect Scatella stagnalis in the following pages. I have described here only those stages that are exhibited in my hurried collection which may not be complete. A study of its complete biology would be of considerable interest; this, however, requires a constant watch of the species at the spot for a fairly long period.

\section{Material.}

The insects were found attached to the growth above the water's edge on the sides of a tank in the laboratory at Plymouth. This growth consists mainly of greenish and brownish algæ which are constantly kept moist by the sea-water from the tank. The algæ, I presume, provide a suitable adults.

* I am grateful to Dr. F. W. Edwards for the identification of the species from the 
feeding ground for the Scatella. Various other micro-organisms, such as the protozoa and bacteria, so common in these places, also possibly supply additional nutriment to the species.

The imagines usually lie motionless on the sides of the tanks and generally abound those tanks without rapid currents. They are small blackish flies with spotted wings. For a detailed description of the adults, reference may be made to Fallen (1823) and Berl. Ent. Zeitsch. (1895).

\section{EGG.}

The egg is $0 \cdot 1 \mathrm{~mm}$. in length and is nearly twice as long as broad. It is more or less bean-shaped, with a slight depression in the middle of the ventral side, both ends of it being somewhat rounded in the same manner and having an equal width. The micropyle is not distinguishable. The chorion is ridged with a number of transverse ripples, giving it as triated appearance, and is blackish in colour. The eggs are found singly, which suggests that they are perhaps not laid in batches.

\section{Larva.}

My collections show that there are at least three instars in the larval life such as are generally met with in the Cyclorrhaphous flies. I have differentiated the stages mainly on the basis of the respiratory system and it may be noted here that I have not seen their moultings.

\section{(i) First Instar (Fig. 1).}

The larva in this stage measures about $1.9 \mathrm{~mm}$. in length with a breadth of $0.4 \mathrm{~mm}$. and is whitish in colour, being more or less transparent. It consists of thirteen segments, the last segment being pushed a little ventralwards. The posterior or the anal end of the larva is truncated and is wider than the anterior end. The caudal branches of the last segment are just visible bearing a pair of spiracles at their blunt ends, one on each side; the larva is metapneustic, there being no other spiracles. The mouth-parts agree closely with those of Ephydra (Ping, 1921). Anteriorly there is a U-shaped mandibular sclerite which is separated from the remaining parts composed of a pair of $\mathrm{H}$-shaped hypostomal sclerites and a pair of lateral pharyngeal plates posteriorly.

\section{(ii) Second Instar.}

The second instar larva measures about $2.8 \mathrm{~mm}$. in length and nearly $0.6 \mathrm{~mm}$. in width. It is brownish in colour and somewhat opaque. The larva becomes amphipneustic, there having appeared a pair of thoracic spiracles now, one on each side of the prothorax, in addition to the pair 
of caudal spiracles which become more pronounced than in the preceding stage. The cephalo-pharyngeal skeleton becomes highly chitinised.

\section{(iii) Third Instar (Fig. 2).}

The third instar or the full-grown larva measures from $5.0 \mathrm{~mm}$. to $5.4 \mathrm{~mm}$. in length (from tip of head to extremity of caudal branches) with

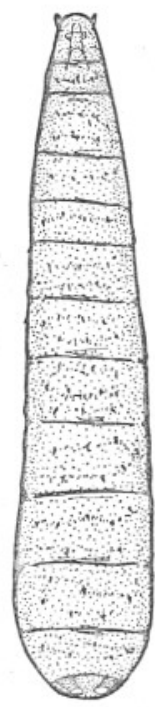

FIG. 1.-First instar larva of Scatella stagnalis.

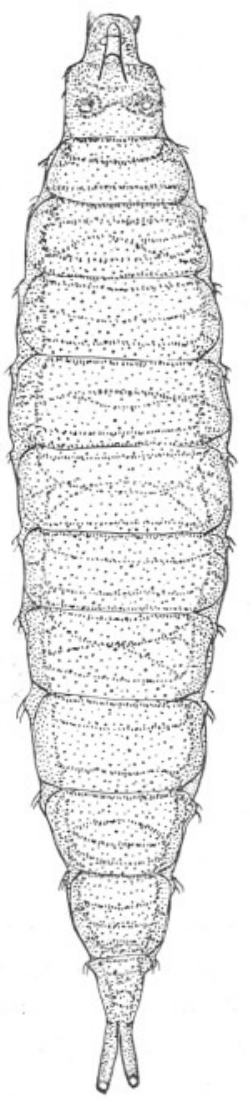

FIG. 2.-Third instar larva of Scatella stagnalis.

a breadth of $1.0 \mathrm{~mm}$. to $1.1 \mathrm{~mm}$. in the widest part; the size thus is variable to some extent. The prothoracic spiracles, one on each side, already mentioned in connection with the preceding stage become sixdigited and the larva as a whole is more strongly chitinised, having an opaque brownish body surface.

It is cylindrical in shape and consists of a retractile head and twelve 
body segments, possessing thirteen segments altogether. The head bears a pair of two-segmented minute antennae, the basal segment of each antenna being much wider than the distal. The body segments, excepting the two or three anteriormost, are not very distinct and are highly wrinkled. The two caudal branches in the last segment are tubular in shape, within which the main tracheæ are extended. At the apex of each of these branches lies a chitinous cap possessing the caudal spiracle in the centre and four fan-shaped membranous structures hanging laterally.

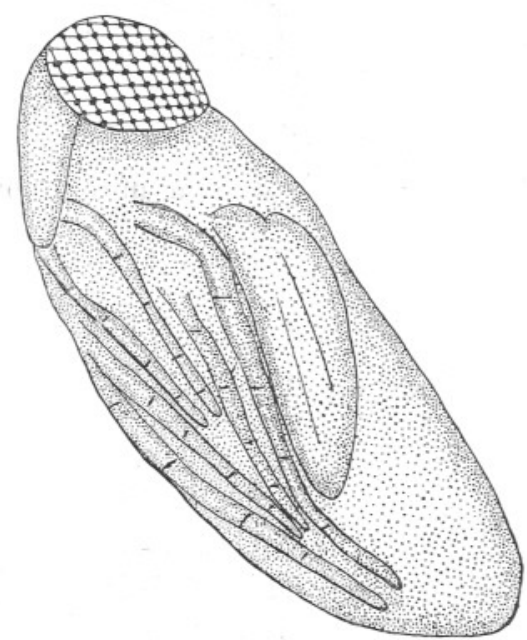

Fig. 3.-Pupa of Scatella stagnalis.

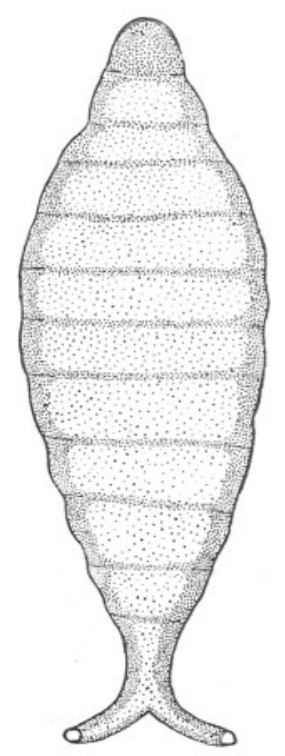

Fig. 4.-Puparium of Scatella stagnalis.

The body is thickly beset with spines which are more prominent dorsally. Each of the first eight abdominal segments bears a pair of nipple-like prolegs which are provided with a number of short setæ. The last pair of prolegs are larger than any of the preceding ones.

\section{Pupa (Fig. 3).}

The pupation takes place within the last larval skin which functions as the puparium (Fig. 4). The anterior three or four segments of the puparium are flattened dorso-ventrally, and posteriorly the puparium is more or less barrel-shaped. The pupæ are attached to the substratum by means of the caudal branches in the puparium and the branches at this stage diverge laterally and are not directed posteriorly as in the larva.

The pupa is much smaller in size than the puparium, being nearly half 
the latter, and is enveloped in a thin transparent saccular sheath through which the imaginal appendages can be clearly distinguished. The pupa measures about $2.3 \mathrm{~mm}$. in length with a width of $0.9 \mathrm{~mm}$.

The anterior end of the pupa is broader than the anal end, and the head possesses a pair of prominent eyes. A pair of small antennal tubercles can be seen at the sides of the head in front of the eyes. The proboscis is flattened and firmly pressed to the body in between the coxæ of the legs. The wings and the three pairs of legs are also closely pressed against the ventral surface of the pupal body.

The imago, when ready to emerge, effects a split at the anterior flattened end of the puparium, through which it subsequently escapes. The split runs along the sides of the puparium, dividing this end of the puparium into two almost similar flaps, one dorsal and one ventral.

The species seems to be fairly free from enemies, as most of the parasitic and predaceous insects find the salinity of the water, in which the Scatella abounds, unsuitable for habitation. Certain mites, however, are often found in the beds of Scatella stagnalis.

\section{REFERENCES.}

Fallen, C. F. 1823. Diptera Sueciae, Vol. I.

Ping, C. 1921. The biology of Ephydra subopaca Loew. Cor. Univ. Agric. Exp. Sta. Ithaca, N.Y., Mem. 49, pp. 557-616.

Berliner Entomologische Zettschrift, XI 4 , 1895, p. 235. 
